\title{
Prawo strony do przeniesienia do rejestru stanu cywilnego małżeństwa jednopłciowego - uwagi na tle orzecznictwa Europejskiego Trybunału Praw Człowieka w Strasburgu
}

Party's right to transcript one's homosexual status to the civil status records - remarks on the jurisprudence of the European Court of Human Rights

\section{STRESZCZENIE}

Zgodnie z polskim prawem, osoba, która za granicą zawarła związek małżeński, może domagać się jego transkrypcji - tj. przeniesienia do rejestru stanu cywilnego. To uprawnienie nie przysługuje jednak wszystkim osobom, które zawarły związek małżeński zgodnie z prawem obowiązującym za granicą. Niemożliwym w Polsce jest, między innymi, przeniesienie do polskiego rejestru aktów stanu cywilnego, małżeństwa homoseksualnego zawartego w innym kraju. W niniejszym artykule autor postara się odpowiedzieć na pytanie, czy stan prawny, gdzie małżeństwo skutecznie zawarte poza granicami Polski, w Polsce nie podlega prawnemu uznaniu, a w konsekwencji nie podlega żadnej ochronie prawnej, jest zgodny z minimalnymi standardami ochrony praw człowieka wytyczanymi Europejską Konwencją o Ochronie Praw Człowieka oraz orzecznictwem Europejskiego Trybunału Praw Człowieka w Strasburgu.

Słowa kluczowe: Prawo administracyjne, transkrypcja, akt stanu cywilnego, ETPC, EKPC, Orlandi, Oliari, Schalk i Kopff, orzecznictwo, LGBT.

\section{WSTĘP}

W XXI wieku - czasach globalizacji, gdy związki małżeńskie zawarte za granicą, często przez przedstawicieli różnych narodowości, są powszechne i równie powszechnie akceptowane, istotnym dobrodziejstwem jest instytucja transmisji. 
Nie wszystkie pary mogą jednak skorzystać z prawa do przeniesienia do krajowego rejestru stanu cywilnego aktu swojego małżeństwa. Uprawnienie to nie przysługuje, m.in. parom homoseksualnym, które zdecydowały się na zawarcie małżeństwa za granicą.

W Polsce, w chwili obecnej prawo krajowe nie daje możliwości sformalizowania związku homoseksualnego ani w formie małżeństwa, ani związku partnerskiego. W obliczu takiej regulacji, a właściwie jej braku, pary homoseksualne będące w pewnym kraju małżeństwem, w Polsce traktowane są jak osoby formalnie obce względem siebie, a co za tym idzie pozbawione uprawnień płynących z faktu zawarcia związku małżeńskiego.

W niniejszym opracowaniu zostanie pokrótce scharakteryzowana instytucja transkrypcji jako jedynej możliwości zalegalizowania w Polsce małżeństwa zawartego za granicą tak między osobami różnych narodowości (małżeństwo binacjonalne), jak i między obywatelami Polski (homonacjonalne). W następnej kolejności, zostaną poczynione postulaty de lege ferenda, po zwięzłym omówieniu spraw wytoczonych przez osoby homoseksualne przed Europejskim Trybunałem Praw Człowieka oraz potencjalnego wpływu wyroków strasburskich na polskiego ustawodawcę.

\section{TRANSKRYPCJA}

Problematyka przeniesienia do krajowego rejestru stanu cywilnego małżeństwa zawartego za granicą nie jest bynajmniej kwestią marginalną. Już w zamierzchłych czasach przedstawiciele różnych narodowości pobierali się, niejednokrotnie zawierając przy tym sojusze czy istotne transakcje gospodarcze. Owe śluby niejednokrotnie zawierane były w różnych od siebie kręgach kulturowych, a także w ramach różnych porządków prawnych.

W Polsce zjawisko zawierania związków małżeńskich za granicą lub z partnerami zza granicy ciągle się rozwija, choć nie tak dynamicznie jak można by się tego spodziewać. Od 1996 roku Główny Urząd Statystyczny publikuje dane dotyczące małżeństw binacjonalnych, odnosząc się jedynie do takich małżeństw, które zostały w Polsce zarejestrowane. Zgodnie z danymi statystycznymi GUS, w 1996 roku zarejestrowano 3154 małżeństwa binacjonalne. W 2004 roku - 4080, a w 2014 roku liczba ta spadła do 3367 małżeństw․ ${ }^{1}$ W 2016 roku były to już 4662 małżeństwa. Należy jednakże podkreślić, że powyższe dane odnoszą się do małżeństw zawartych

1 Dane Głównego Urzędu Statystycznego [za:] P. Szukalski, Małżéstwa binacjonalne [w:] Demografia i Gerontologia Spoteczna - Biuletyn Informacyjny 2015, nr 7; dost. tutaj: http://dspace. uni.lodz.pl:8080/xmlui/bitstream/handle/11089/12441/2015-07\%20Matżeństwa\%20binacjonalne. pdf? sequence $=1 \&$ isAllowed $=y$ [dostęp z dnia 21 maja 2018 r.]; str. 1 . 
w Polsce, pomijając małżeństwa binacjonalne zawarte za granicą, których liczba np. w latach 2009 - 2014 utrzymywała się na poziomie ok. 11-12 tys ${ }^{2}$.

Pomimo powszechności migracji ludności różnych narodowości i kultur, małżeństwa zawarte poza granicami RP nie zyskują ex lege wszystkich uprawnień małżeńskich przewidzianych polskim prawem. Muszą się one borykać nie tylko z problemami natury kulturowej ${ }^{3}$, ale także prawnej. Tym małżeństwom, które zdecydowały się na ślub za granicą, służy instytucja transkrypcji tj. przeniesienia do rejestru stanu cywilnego aktu małżeństwa zawartego za granicą. Skorzystanie z dobrodziejstwa transkrypcji jest oczywiście fakultatywne, jednakże nie sposób nie dostrzec zalet tego rozwiązania. Dopiero po dokonaniu transkrypcji małżeństwo zawarte za granicą będzie w Polsce zrównane w prawach z tym „krajowym”. $\mathrm{W}$ ten sposób małżonkowie będą mogli korzystać z przywilejów przewidzianych dla małżeństw krajowych, m.in. z możliwości wspólnego rozliczania się z podatku dochodowego od osób fizycznych.

Transkrypcja uregulowana jest $\mathrm{w}$ art. 104 i nast. ustawy Prawo o aktach stanu cywilnego ${ }^{4}$. Polega ona na przeniesieniu, w sposób literalny i wierny, treści zagranicznego dokumentu stanu cywilnego. Wykluczona jest jakakolwiek ingerencja w treść aktu stanu cywilnego (choć pod pewnymi warunkami dopuszczalne jest dostosowanie pisowni do reguł pisowni polskiej). Transkrybować można jedynie taki dokument, który w państwie wystawienia jest uznawany za dokument stanu cywilnego i ma moc dokumentu urzędowego. Musi on także zostać wydany przez właściwy organ w państwie obcym, a ponadto, polski kierownik Urzędu stanu cywilnego nie może mieć wątpliwości dotyczących autentyczności dokumentu.

Aby transkrybować akt, wystarczy zgłosić się do kierownika wybranego urzędu stanu cywilnego z wnioskiem o transkrypcję aktu. Wnioskodawcą musi być osoba, której zdarzenie podlegające transkrypcji dotyczy lub która wykaże swój interes prawny w transkrypcji aktu (notabene w przypadku aktu zgonu - wystarczy interes faktyczny). Możliwa jest również dokonanie transkrypcji z urzędu.

Warto jedynie nadmienić, że w pewnych okolicznościach dokonanie transkrypcji jest obowiązkowe. Dotyczy to sytuacji, w której obywatel polski, którego dotyczy zagraniczny dokument stanu cywilnego, posiada sporządzony na terytorium RP akt stanu cywilnego potwierdzający zdarzenie wcześniejsze i żąda dokonania czynności z zakresu rejestracji stanu cywilnego lub ubiega się o polski dokument tożsamości lub nadanie numeru PESEL.

2 op. cit. s. 4

3 zob. E. Żywucka - Kozłowska, A. Opalska; Binacjonalne związi małżeńskie; [w:] Problemy matżeństwa i rodziny w prawodawstwie polskim, międzynarodowym i kanonicznym; red. R. Sztychmiler, J. Krzywkowska, M. Paszkowski, Olsztyn 2017.

4 Ustawa z dnia 28 listopada 2014 r. Prawo o aktach stanu cywilnego tekst jednolity Dz. U. z 2016 r. poz. 2064 z późn. zm. 
Skuteczna transkrypcja ma ten efekt, że zostaje sporządzony polski akt stanu cywilnego ${ }^{5}$. W ten sposób małżeństwo zawarte za granicą przez obywateli Polski lub osoby np. zamieszkujące w Polsce, będzie traktowane w polskim porządku prawnym na równi z małżeństwem zawartym w RP.

Czy jednak zawsze akt małżeństwa zawartego za granicą zostanie bezproblemowo przeniesiony do polskiego rejestru stanu cywilnego? Odpowiedź na to pytanie jest oczywiście przecząca. Zgodnie z treścią art. 107 Prawa o aktach stanu cywilnego, w trzech przypadkach kierownik USC odmówi dokonania transkrypcji. Odmowa następuje wówczas w formie decyzji administracyjnej, od której przysługuje odwołanie do właściwego miejscowo wojewody. Warto podkreślić, że w przypadku ziszczenia się któregokolwiek warunku, kierownik USC będzie musiał odmówić dokonania transkrypcji, co oznacza, że jest to tzw. decyzja związana. Odmowa dokonania transkrypcji nastąpi, gdy:

1) dokument w państwie wystawienia nie jest uznawany za dokument stanu cywilnego lub nie ma mocy dokumentu urzędowego, lub nie został wydany przez właściwy organ, lub budzi wątpliwości co do swojej autentyczności, lub potwierdza zdarzenie inne niż urodzenie, małżeństwo lub zgon;

2) zagraniczny dokument powstał w wyniku transkrypcji w państwie innym niż państwo zdarzenia;

3) transkrypcja byłaby sprzeczna z podstawowymi zasadami porządku prawnego Rzeczypospolitej Polskiej.

\section{TRANSKRYPCJA ZAWARTEGO ZA GRANICĄ MAŁŻEŃSTWA JEDNOPŁCIOWEGO}

Z podanych powyżej okoliczności wyłączających możliwość dokonania transkrypcji, najistotniejszą z uwag na temat niniejszego artykułu, jest niewątpliwie sprzeczność z podstawowymi zasadami porządku prawnego Rzeczypospolitej Polskiej. Nie pozostawia wątpliwości, że w obecnym stanie prawnym nie jest możliwe przeniesienie do polskiego rejestru aktów stanu cywilnego małżeństwa jednopłciowego.

Jako dygresję można jedynie potraktować wzmiankę, że jeśli para heteroseksualna lub homoseksualna zawrze związek partnerski za granicą (np. francuski pacte civil de solidarité - tzw. PACS ${ }^{6}$ ) - jego również nie da się przenieść do polskiego rejestru z uwagi na fakt, że polskie prawo nie zna instytucji związku partnerskiego. W tym zakresie prawo na równi traktuje homo i heteroseksualistów odmawiając im prawa do sformalizowania ich związku w sposób inny niż w drodze zawarcia

5 zob. np. postanowienie Sądu Najwyższego z dnia 3 czerwca 2011 r. sygn. akt III CSK 259/10.

6 Article 515-1, ustawy Code Civil, t.j. z dnia 3 stycznia 2018 roku z późn. zm. 
małżeństwa (lub, jak lubią powtarzać niektóre głosy w dyskursie publicznym w drodze umowy spółki cywilnej).

Wracając jednak do tematu niniejszego opracowania - transkrypcja małżeństwa jednopłciowego jest, zgodnie z polskim prawem, niemożliwa. Najbardziej prozaicznym wydaje się powód techniczny - w polskim akcie małżeństwa jest miejsce na wpisanie „męża” i ,żony”. Podobnie, jak w akcie urodzenia dziecka wpisuje się „ojca” i „matkę”. Jednoznacznie negatywnie należałoby ocenić hipotetyczne zachowanie urzędnika polegające np. na wpisaniu w rubrykę „mąż” danych jednej z żon w małżeństwie lesbijek ${ }^{7}$. Można by nawet zastanawiać się, czy takie zachowanie nie nosiłoby znamion przestępstwa fałszerstwa intelektualnego stypizowanego w art. $271 \S 1$ Kodeksu karnego ${ }^{8}$.

Przyjmując również, że nie sposób dyskutować z postanowieniami Konstytucjị, należy podkreślić, że zgodnie z ustawą zasadniczą małżeństwo to związek kobiety i mężczyzny. Sformułowanie to, wprowadzone na etapie czytania projektu przez Zgromadzenie Narodowe, może sugerować cel, który przyświecał ustawodawcy. „Wskazuje się, że celem przyjętej zmiany było wykluczenie możliwości legalizacji małżeństw homoseksualnych ${ }^{10}$ ". Artykuł 18 Konstytucji, zdaniem autora, nie pozostawia dowolności interpretacyjnej.

W kontekście tematyki niniejszego artykułu istotną rolę pełni także art. 12 Europejskiej Konwencji o Ochronie Praw Człowieka ${ }^{11}$, w którym podkreślono prawo mężczyzn i kobiet $w$ wieku małżeńskim do zawarcia małżeństwa i założenia rodziny w sposób zgodny z ustawami krajowymi regulującymi korzystanie z tego prawa. Polskie sądy przyjmują jednolitą linię orzeczniczą w kwestii niedopuszczalności przeniesienia do rejestru stanu cywilnego aktu małżeństwa jednopłciowego. Wyroki w takich sprawach, ze względu na swój medialny charakter, od czasu do czasu pojawiają się w dyskursie publicznym. Każdorazowo budzą wówczas gorące emocje i powodują ożywione dyskusje polskiego społeczeństwa (a przynajmniej jego części).

W lutym 2018 r. opinia publiczna znów na chwilę zainteresowała się prawem gejów i lesbijek do dokonania transkrypcji, wraz z ogłoszeniem kolejnego, zgod-

7 Podobnie np. wyrok Naczelnego Sądu Administracyjnego z dnia 17 grudnia 2014 r., sygn. akt II OSK 1298/13; Wyrok Wojewódzkiego Sądu Administracyjnego w Gliwicach z dnia 6 kwietnia 2016 r., sygn. akt. II SA/Gl 1157/15.

8 Ustawa z dnia 6 czerwca 1997 r. Kodeks karny tekst jedn. Dz. U. z 2017 r. poz. 2204 z późn. zm.

9 Konstytucja Rzeczypospolitej Polskiej z dnia 2 kwietnia 1997 r., Dz. U. z 1997 r. nr 78. poz. 483 z późn. zm.

10 L. Garlicki, [w:] Konstytucja Rzeczypospolitej Polskiej. Komentarz. Tom I [red.] L. Garlicki, M. Zubik, Warszawa 2016.

11 Konwencja o Ochronie Praw Człowieka i Podstawowych Wolności, Dz. U. z 1993 r. nr 61 poz. 284 z późn. zm. 
nego z dotychczasową linią orzeczniczą wyroku ${ }^{12}$ Naczelnego Sądu Administracyjnego. W orzeczeniu tym NSA oddalił skargę kasacyjną dwóch kobiet, które próbowały dochodzić przed sądem administracyjnym ochrony swojego prawa do rejestracji w Polsce aktu małżeństwa, które zostało zawarte za granicą na podstawie tam obowiązujących przepisów prawa.

Skarżące podnosiły w szczególności, że polskie prawo, a właściwie jego interpretacja, w zakresie, w jakim nie pozwala im na transkrypcję swojego aktu małżeństwa, łamie postanowienia Europejskiej Konwencji o Ochronie Praw Człowieka ${ }^{13}$. Zarzucono, że zostały naruszone: art. 8 (prawo do życia rodzinnego) oraz art. 14 (zakaz dyskryminacji) w zw. $z$ art. 8 EKPC, gdyż odmowa dokonania transkrypcji, w opinii skarżących, „stanowiła przejaw dyskryminacji ze względu na orientację seksualną w zakresie dostępu do korzystania przez skarżące z prawa do życia rodzinnego ${ }^{14}$ ". Aby zastanowić się nad tym, czy rzeczywiście z Europejskiej Konwencji o Ochronie Praw Człowieka wywodzi się prawo do uznania małżeństwa homoseksualnego zawartego za granicą, warto odwołać się do przywoływanych przez skarżące spraw toczących się przed Europejskim Trybunałem Praw Człowieka. W celu ukazania ewolucji orzecznictwa ETPC, warto przytoczyć trzy najważniejsze w tym kontekście sprawy, w kolejności w jakiej zapadły poszczególne wyroki.

\section{SPRAWA SCHALK I KOPFF PRZECIWKO AUSTRII}

W 2010 roku Europejski Trybunał Praw Człowieka wydał uznany szybko za przykład nowego podejścia Trybunału do praw homoseksualistów ${ }^{15}$ wydał wyrok w sprawie wytoczonej przeciwko Austrii przez parę mężczyzn będących w relacji homoseksualnej, który został szybko uznany za przykład... Próbowali oni, nieskutecznie, domagać się od władz austriackich wydania zezwolenia na zawarcie małżeństwa. W tamtym czasie w Austrii prawo nie przewidywało małżeństw jednopłciowych, stąd też żądania skarżących nie zostały uwzględnione w toku postępowania przed organami tego kraju. Już jednak w czasie trwania postępowania przed ETPC, w roku 2010, Austria przyjęła prawo pozwalające homoseksualistom na zawieranie związków partnerskich. Zgodnie z nowymi przepisami, homoseksualiści zyskali przywileje, którymi już cieszyli się w Austrii małżonkowie - między innymi w kwestiach podatkowych, spadkowych czy socjalnych. Warto zauważyć,

${ }^{12}$ Wyrok Naczelnego Sądu Administracyjnego z dnia 28 lutego 2018 r., sygn. akt II OSK $1112 / 16$.

${ }_{13}$ Ibidem; zob. także wyrok Wojewódzkiego Sądu Administracyjnego w Gdańsku z dnia 14 stycznia 2016 r. sygn. akt III SA/Gd 835/15.

${ }^{14}$ Ibidem.

15 Wyrok Europejskiego Trybunału Praw Człowieka z dnia 24 czerwca 2010 r. w sprawie Schalk i Kopff p. Austrii, skarga nr 30141/04. 
że austriacki ustawodawca zdecydował o pozostawieniu pewnych różnic między małżeństwem a związkiem partnerskim przejawiających się np. w różnych organach, przed którymi zawiera się każde z nich. Główną różnicą pozostawała kwestia ograniczenia par homoseksualnych pozostających w zalegalizowanym związku partnerskim w prawie do adopcji dzieci oraz w prawie do korzystania ze sztucznego zapłodnienia ${ }^{16}$.

W czasie, kiedy sprawa Schalk i Kopff toczyła się przed Trybunałem, pomiędzy państwami Rady Europy nie było konsensusu co do statusu par homoseksualnych. Jedynie sześć spośród 47 państw Rady Europy przyznawało parom homoseksualnym prawo do zawarcia małżeństwa. 13 państw, pomimo odmowy przyznania homoseksualistom prawa do małżeństwa, stworzyło pewne ramy prawne dla oficjalnego uznania ich związków. W tamtym czasie także inne państwa przejawiały zainteresowanie wprowadzeniem jakiegoś rozwiązania, które wydobywałoby pary homoseksualne z prawnej próżni ${ }^{17}$.

W swoim wyroku Europejski Trybunał Praw Człowieka podkreślił, że art. 12 Konwencji chroni prawo do zawarcia małżeństwa gwarantowane mężczyźnie i kobiecie. Ponadto wskazał, że istotnym aspektem prawa do zawarcia związku małżeńskiego jest prawo do założenia rodziny. Nie przychylił się jednak do argumentacji skarżących, że zgodnie z ewolucyjną wykładnią Konwencji, art. 12 powinien być traktowany jako gwarantujący parom jednopłciowym prawo do zawarcia związku małżeńskiego. Trybunał uznał, że każde państwo samo najlepiej jest w stanie ocenić, jakie są potrzeby jego społeczeństwa, szczególnie bacząc na istotny status małżeństwa w kulturze danego kraju. Podkreślony został brak ogólnoeuropejskiego konsensusu odnoszącego się do uznania małżeństw jednopłciowych a w konsekwencji uznano, że art. 12 nie został złamany ${ }^{18}$.

Trybunał odniósł się w omawianym wyroku także do tego, czym jest związek homoseksualny. Nie poddając pod wątpliwość, że homoseksualiści korzystają z ochrony swojego życia prywatnego, w sposób nowatorski uznał, że przysługuje im także ochrona ich życia rodzinnego w obrębie związku, jaki tworzą ${ }^{19}$. Podkreślono, że w ostatnich latach nastąpiła znacząca ewolucja podejścia europejskiego społeczeństwa do kwestii praw i statusu homoseksualistów, jednakże państwa wciąż cieszą się marginesem swobody oceny w kwestii tego jak i kiedy wprowadzą ewentualne zmiany w prawie krajowym.

Zrównując w zakresie korzystania z ochrony życia rodzinnego homo i heteroseksualne pary, Europejski Trybunał Praw Człowieka otworzył sobie drogę do bardziej otwartego sposobu interpretacji Konwencji zgodnie z teorią, że Konwen-

\footnotetext{
16 Ibidem, § 16 i nast.

17 Ibidem, § 27 i nast.

18 Ibidem, § 54 i nast.

19 Ibidem, § 90 i nast.
} 
cja powinna być interpretowana w świetle zmieniającej się rzeczywistości. W ten sposób, w obrębie jednego wyroku odwołał się zarówno do doktryny marginesu swobody oceny oraz doktryny żywego instrumentu ${ }^{20}$. Choć Trybunał nie stwierdził naruszenia Konwencji (także z uwagi na zmienione w trakcie procesu prawo krajowe), wyrok ten zmienił linię orzeczniczą ETPC i stanowił zaczątek nowej tendencji.

\section{SPRAWA OLIARI I INNI PRZECIWKO WŁOCHOM}

Po trwającym pięć utrwalaniu się linii orzeczniczej, w 2015 r. zapadł kolejny przełomowy wyrok ${ }^{21}$. Trzy pary homoseksualne próbowały nieskutecznie dochodzić przed sądami włoskimi swojego prawa do zawarcia małżeństwa. Skarżący podnosili, że prawo włoskie, uniemożliwiające im zawarcie związków małżeńskich, jest sprzeczne z włoską konstytucją oraz Konwencją. Zwrócono również uwagę, że włoskie prawo nie pozwala także na zawarcie innego rodzaju sformalizowanego związku między osobami tej samej płci, co miało być przejawem dyskryminacji ze względu na orientację seksualną.

Włochy co prawda uznawały prawo osób tej samej płci do zawarcia związku cywilnego (civil unions), jednakże było to możliwe jedynie w niektórych regionach a nawet tam miało jedynie znaczenie symboliczne. W czasie, gdy wydawano wyrok w sprawie Oliari i inni p. Włochom, 11 państw Rady Europy uznawało małżeństwa jednopłciowe. Osiemnaście z państw (w tym niektóre spośród pierwszej grupy), w jakiś sposób zapewniały prawną regulację związków homoseksualnych, czy to w formie związku partnerskiego czy związku cywilnego. W sumie, 24 spośród 47 państw Rady Europy zdecydowało się na unormowanie sprawy związków jednopłciowych. Jednoznacznie dało się więc zauważyć, że w ciągu 5 lat od wyroku w sprawie Schalk i Kopff p. Austrii, tendencja ciągle rozwijała się̨22. W społeczeństwie europejskim istniała zatem wola, by w coraz pełniejszy sposób zapewnić homoseksualistom realizację ich prawa do ochrony nie tylko życia prywatnego, ale i rodzinnego. „Ta sama potrzeba i wola zapewnienia uznania prawnego i ochrony została wyrażona już piętnaście lat temu przez Zgromadzenie Parlamentarne Rady Europy, które zaleciło Komitetowi Ministrów wezwanie państw członkowskich m.in. do przyjęcia przepisów umożliwiających istnienie zarejestrowanych związków partnerskich, a później przez Komitet Ministrów (w zaleceniu CM/

${ }^{20}$ Zob. szerzej np. A. Paprocka Budowanie tożsamości europejskiej w orzecznictwie Europejskiego Trybunału Praw Człowieka dost. tutaj: http://www.lex.pl/czytaj/-/artykul/strasburski-trybunal-buduje-europejska-tozsamosc [dostęp z dnia 20 maja 2018 r.].

${ }^{21}$ Wyrok ETPC z dnia 21 października 2015 r. w sprawie Oliari i Inni p. Włochom skargi nr 18766/11 i 36030/11.

${ }^{22}$ Ibidem $\S 53$ i nast. 
Rec(2010)5), który zwrócił się do państw członkowskich, w których ustawodawstwo krajowe nie uznawało ani nie przyznawało praw lub obowiązków dotyczących partnerstwa osób tej samej płci, o rozważenie możliwości zapewnienia takim parom prawnych lub innych środków rozwiązania praktycznych problemów odnoszących się do rzeczywistości społecznej, w której zmuszone są żyć23".

W wyroku Trybunał podtrzymał stanowisko wyrażone w sprawie Schalk i Kopff p. Austrii. Związek homoseksualny to rodzina, która zgodnie z postanowieniami Konwencji wymaga ochrony i uznania prawnego. To, co zmieniło się w podejściu ETPC do kwestii związków homoseksualnych to uznanie, że państwa już nie mogą cieszyć się tak szerokim jak niegdyś marginesem swobody uznania. W zmieniającej się europejskiej rzeczywistości, brak regulacji prawnej umożliwiającej formalne zawarcie związku jednopłciowego, jest według Trybunału naruszeniem prawa do życia prywatnego i rodzinnego.

Uznano, że Włochy nie dopełniły swojego pozytywnego obowiązku jakim było poszanowanie prawa do życia rodzinnego i prywatnego skarżących, co powinny były uczynić wprowadzając odpowiednie regulacje dotyczące związków partnerskich. Szczególnie, że regulacje pozornie mogące zostać uznane za normujące status par jednopłciowych, nie pociągały za sobą istotnych skutków prawnych. Z uwagi na powyższe, Trybunał stwierdził naruszenie przez Włochy art. 8 Konwencji24.

Warto zauważyć, że wyrok Trybunału zbiegł się w czasie z trwającymi we włoskim parlamencie pracami nad legalizacją związków partnerskich ${ }^{25}$. Wydaje się zatem prawdopodobnym założenie, że owo rozstrzygnięcie w sposób znaczący wpłynęło na to, że Włochy wprowadziły w 2016 r. ustawę zezwalającą homoseksualistom na zawarcie związku partnerskiego. Dzięki nowej regulacji, włoskie pary, które zawarły związek partnerski, mogą cieszyć się z przywilejów w zakresie m.in. prawa podatkowego, a włoskie prawo zostało dostosowane do standardów konwencyjnych.

\section{SPRAWA ORLANDI PRZECIWKO WŁOCHOM}

Sego rodzaju następstwem wyroku w sprawie Oliari i Inni p. Włochom, był zapadły w grudniu 2017 r. wyrok ${ }^{26}$ w sprawie Orlandi i Inni p. Włochom. W tym

${ }^{23}$ M. A. Nowicki, Omówienie orzeczenia Oliari i Inni p. Włochom, dost. tutaj: https://www. hfhr.pl/wp-content/uploads/2015/10/omowienie_orzeczenia_oliari_i_inni_przeciwko_wlochom.pdf [dostęp z dnia 21 maja 2018 r.].

${ }^{24}$ Wyrok w sprawie Oliari i Inni p. Włochom, $§ 184$ i nast.

25 zob. Europejski Trybunat Praw Człowieka żąda, by Włochy zinstytucjonalizowały homoseksualne zwiazki partnerskie, dost. tutaj: http://www.ordoiuris.pl/rodzina-i-malzenstwo/europejski-trybunal-praw-czlowieka-zada-wlochy-zinstytucjonalizowaly [dostęp z dnia 21 maja 2018 r.].

${ }^{26}$ Wyrok ETPC z dnia 14 grudnia 2017 r. w sprawie Orlandi i Inni p. Włochom, skarga nr $26431 / 12$. 
wyroku Trybunał jeszcze dobitniej podkreślił potrzebę rozpostarcia ochrony nad osobami homoseksualnymi tak, by mogły one korzystać z pełni praw gwarantowanych w ramach Europejskiej Konwencji o Ochronie Praw Człowieka.

W tym przypadku skarżącymi było 6 par, które zawarły związki małżeńskie poza Włochami. Przed złożeniem skargi, skarżący starali się zarejestrować swoje związki we Włoszech, spotykając się jednak z odmową. Warto podkreślić, że skarga została wniesiona w 2012 r., czyli jeszcze przed wprowadzeniem we Włoszech nowego prawa pozwalającego homoseksualistom na zawieranie związków partnerskich. Po wejściu w życie nowych przepisów, kilkoro skarżących skorzystało z prawa do zawarcia ważnego w świetle włoskiego prawa związku partnerskiego.

Trybunał zwrócił uwagę, że nawet od czasu wyroku w sprawie Oliari, społeczeństwo europejskie poczyniło kolejne kroki w kierunku uregulowania sytuacji par homoseksualnych. W 2017 r. bowiem, 15 państw członkowskich Rady Europy uznawało małżeństwa jednopłciowe. $\mathrm{W}$ sumie 27 państw członkowskich w jakiś sposób przyznawało parom jednopłciowym prawo do zalegalizowania swojego związku.

W wyroku Trybunał przyznał, że państwa Rady Europy wciąż cieszą się swobodą oceny w kwestii tego, czy i w jaki sposób sformułować prawo homoseksualistów do zawarcia małżeństwa w ramach porządku krajowego. Podkreślono jednak, że para jednopłciowa niezależnie od zapatrywania państwa na powyższe zagadnienie - ma prawo do włożenia ich związku w jakieś ramy prawne. Pozostawienie $\mathrm{w}$ formalnej pustce związku, który w innych krajach traktowany jest jako zgodnie z prawem zawarte małżeństwo lub związek partnerski, stoi w sprzeczności z poszanowaniem prawa do życia prywatnego i rodzinnego. Pozostawienie takiego związku bez ochrony prawnej, w opinii Trybunału, stanowiło naruszenie art. 8 Konwencji

Wyrok w sprawie Orlandi i Inni p. Włochom znów przesunął granicę, którą wytyczył Trybunał, wskazując minimalny standard ochrony praw par jednopłciowych. Wraz ze zmieniającym się podejściem społeczności europejskiej i ewolucyjną wykładnią Konwencji - Trybunał stara się zapewnić możliwie najpełniejsze poszanowanie praw jednostek w całym systemie Rady Europy.

\section{SPRAWY STRASBURSKIE A RZECZYWISTOŚĆ POLSKA}

Do wyroku w sprawie Orlandi i Inni p. Włochom dwóch sędziów złożyło zdania odrębne. Jednym z nich był sędzia Krzysztof Wojtyczek, który podkreślił, że wykładnia uznana przez ETPC za właściwą, sprzeczna jest z założeniami Konwencji. Wskazano, że Trybunał w wyroku w sprawie Orlandi i Inni, nałożył na Włochy pozytywne obowiązki, których nie sposób wyprowadzić z Konwencji. Fakt, że to właśnie polski sędzia, w kontekście podobieństwa między polskim a włoskim (przed wprowadzeniem nowego prawa) systemem, wydaje się znamienny. 
Odmowę zarejestrowania małżeństw motywowano bowiem we Włoszech, podobnie jak aktualnie motywuje się to w Polsce, sprzecznością z normami porządku publicznego ${ }^{27}$. Na podobieństwo między oboma systemami (zanim Włochy wprowadziły nowe regulacje) zwróciła także uwagę Helsińska Fundacja Praw Człowieka w swojej opinii przyjaciela sądu ${ }^{28}$. Także $\mathrm{w}$ treści wyroku ${ }^{29} \mathrm{w}$ sprawie Orlandi i Inni, przywołano wyniki badań polskiego społeczeństwa i wskazano, że poparcie dla związków partnerskich się w Polsce zwiększa.

Według badañ ${ }^{30}$ CBOS opublikowanych w 2013 r., aż 68\% ankietowanych nie akceptuje legalizacji małżeństw homoseksualnych. Natomiast $60 \%$ badanych nie zgadza się na wprowadzenie związków partnerskich dla par homoseksualnych (podczas gdy $85 \%$ chciałaby związków partnerskich dla par heteroseksualnych). Jednakże zgodnie z badaniem, poparcie dla homoseksualnych związków partnerskich od 2011 roku wzrosło do 33\%, czyli o 8 punktów.

Podobne badania ${ }^{31}$ CBOS opublikował w 2017 r. Tym razem przeciw legalizacji jednopłciowych związków małżeńskich opowiedziało się $64 \%$ respondentów. Podczas, gdy $89 \%$ badanych jest pozytywnie nastawiona do pomysłu wprowadzenia heteroseksualnych związków partnerskich, to jednak 56\% pytanych wciąż nie akceptuje homoseksualnych związków partnerskich. Z powyższego wynika, że polskie społeczeństwo, choć nieśmiało otwiera się na prawa homoseksualistów, robi to jednak wolniej niż ogół społeczeństw europejskich.

\section{PODSUMOWANIE}

Czy w Polskim porządku prawnym dopuszczalne jest dziś dokonanie transkrypcji zagranicznego małżeństwa homoseksualnego? Zdecydowanie nie. Nie sposób jednak w dzisiejszej rzeczywistości przewidzieć, co stanie się za dziesięć lat, z uwagi na dynamiczność zmian w Europie w porównaniu z powolną zmianą postrzegania kwestii społecznych przez Polaków. Czy w najbliższym czasie czeka

${ }^{27}$ Zob. M. A. Nowicki, Omówienie orzeczenia Orlandi i Inni p. Włochom, dost. tutaj: https://www.hfhr.pl/wp-content/uploads/2018/01/Omowienie_orzeczenia_Orlandi_i_inni_przeciwko_Wlochom-1.pdf [dostęp z dnia 21 maja 2018 r.].

${ }_{28}$ Written Comments by the Helsinki Foundation for Human Rights z dnia 25 lutego 2014 r. dost. tutaj: http://www.hfhrpol.waw.pl/precedens/images/Orlandi_amicus_ETPC.pdf [dostęp z dnia 21 maja 2018 r.].

${ }^{29}$ Wyrok w sprawie Orlandi i Inni p. Włochom, §§ $177-181$.

${ }^{30}$ Komunikat z badań BS/24/2013 Stosunek do praw gejów i lesbijek oraz zwiazków partnerskich, [op.] M. Feliksiak, dost. tutaj: https://www.cbos.pl/SPISKOM.POL/2013/K_024_13.PDF [dostęp z dnia 21 maja 2018 r.].

31 Komunikat z badań nr 174/2017 Stosunek do osób o orientacji homoseksualnej i zwiazków partnerskich, [op.] M. Feliksiak, dost. tutaj: https://www.cbos.pl/SPISKOM.POL/2017/K_174_17. PDF [dostęp z dnia 21 maja 2018 r.]. 
nas rewolucja $\mathrm{w}$ kwestii możliwości zarejestrowania w Polsce jednopłciowego związku małżeńskiego zawartego za granicą? Czy może polski ustawodawca zdecyduje się na wprowadzenie do porządku prawnego związków partnerskich tak, by małżeństwa homoseksualne miały możliwość zarejestrowania się przynajmniej jako związek partnerski?

Nie sposób odpowiedzieć na te pytania jednoznacznie. Jeśli skarżące, wobec których wyrok wydał Naczelny Sąd Administracyjny 28 lutego 2018 r. zdecydują się na złożenie skargi do Europejskiego Trybunału Praw Człowieka - prawdopodobnie czeka nas, Polaków, ożywiona dyskusja na ten temat. Trybunał bowiem, mimo pewnego kłopotu z szybkim wyrokowaniem, już niejednokrotnie wydawał wyroki, które wpływały w sposób niebagatelny na polskie prawo. Biorąc pod uwagę tendencję orzeczniczą i stanowczość Trybunału w kwestii kierunku, w którym powinna zmierzać ochrona praw osób będących w związkach jednopłciowych, można domyślać się, że Trybunał dokona reiteracji swojej argumentacji. W szczególności, że okoliczności sprawy zostały już pokrótce przedstawione Trybunałowi we wspomnianej już opinii przyjaciela sądu wydanej przez HFPC. Choć oczywiście nie sposób, bez dokładnej wiedzy na temat okoliczności konkretnej sprawy, przewidywać jakie rozstrzygnięcie zapadłoby w Strasburgu.

Mimo tylu niewiadomych, warto już dziś zastanowić się, czy polskie prawo rzeczywiście chroni osoby, które żyją w związkach homoseksualnych w Polsce. Wydaje się, że nie sposób dłużej udawać, że problem nie istnieje. Bezdyskusyjnym faktem jest, że nie wszyscy obywatele korzystają z takich samych uprawnień, a źródłem tych różnic jest niewątpliwie ich orientacja seksualna.

Wydaje się, że Polska jako kraj, ale przede wszystkim jako społeczeństwo, powinna raz jeszcze zastanowić się nad możliwością przyjęcia takiego prawa, które pozwoliłoby na ochronę prawa do życia prywatnego i rodzinnego osób homoseksualnych. Niewątpliwie Polska nie jest jeszcze gotowa na małżeństwa osób tej samej płci. Być może, należy zacząć od wprowadzenia instytucji związków partnerskich, aby położyć grunt pod ewentualną śmielszą reformę. Z pewnością, aby zapewnić osobom pozostającym w związkach jednopłciowych ochronę ich praw, praw każdego człowieka do ochrony jego życia prywatnego i rodzinnego, należy wyjść z bezpiecznej strefy. Odrzucić uprzedzenia, a skupić na tym, co nas łączy - na człowieczeństwie. 


\section{BIBLIOGRAFIA}

A. Paprocka Budowanie tożsamości europejskiej w orzecznictwie Europejskiego Trybunału Praw Człowieka dost. tutaj: http://www.lex.pl/czytaj/-/artykul/strasburski-trybunal-buduje-europejska-tozsamosc [dostęp z dnia 20 maja 2018 r.].

Dane Głównego Urzędu Statystycznego [za:] P. Szukalski, Matżeństwa binacjonalne [w:] Demografia $i$ Gerontologia Społeczna - Biuletyn Informacyjny 2015, nr 7; dost. tutaj: http://dspace.uni. lodz.pl:8080/xmlui/bitstream/handle/11089/12441/2015-07\%20Matzeństwa\%20binacjonalne. pdf? sequence $=1 \&$ is Allowed $=y$ [dostęp z dnia 21 maja 2018 r.];

E. Żywucka - Kozłowska, A. Opalska; Binacjonalne zwiazki matżeńskie; [w:] Problemy matżeństwa $i$ rodziny $w$ prawodawstwie polskim, międzynarodowym i kanonicznym; red. R. Sztychmiler, J. Krzywkowska, M. Paszkowski, Olsztyn 2017

Europejski Trybunał Praw Człowieka żąda, by Włochy zinstytucjonalizowały homoseksualne zwiazki partnerskie, dost. tutaj: http://www.ordoiuris.pl/rodzina-i-malzenstwo/europejski-trybunal-praw -czlowieka-zada-wlochy-zinstytucjonalizowaly [dostęp z dnia 21 maja 2018 r.].

Komunikat z badań BS/24/2013 Stosunek do praw gejów i lesbijek oraz zwiazków partnerskich, [op.] M. Feliksiak, dost. tutaj: https://www.cbos.pl/SPISKOM.POL/2013/K_024_13.PDF [dostęp $\mathrm{z}$ dnia 21 maja 2018 r.].

Komunikat z badań nr 174/2017 Stosunek do osób o orientacji homoseksualnej i związków partnerskich, [op.] M. Feliksiak, dost. tutaj: https://www.cbos.pl/SPISKOM.POL/2017/K_174_17.PDF [dostęp z dnia 21 maja 2018 r.].

Konstytucja Rzeczypospolitej Polskiej z dnia 2 kwietnia 1997 r., Dz. U. z 1997 r. nr 78. poz. 483 z późn. $\mathrm{zm}$.

Konwencja o Ochronie Praw Człowieka i Podstawowych Wolności, Dz. U. z 1993 r. nr 61 poz. 284 z późn. zm.

L. Garlicki, [w:] Konstytucja Rzeczypospolitej Polskiej. Komentarz. Tom I [red.] L. Garlicki, M. Zubik, Warszawa 2016.

M. A. Nowicki, Omówienie orzeczenia Oliari i Inni p. Włochom, dost. tutaj: https://www.hfhr.pl/ wp-content/uploads/2015/10/omowienie_orzeczenia_oliari_i_inni_przeciwko_wlochom.pdf [dostęp z dnia 21 maja 2018 r.].

Postanowienie Sądu Najwyższego z dnia 3 czerwca 2011 r. sygn. akt III CSK 259/10

Ustawa Code Civil, t.j. Ustawa z dnia 3 stycznia 2018 roku z późn. zm.

Ustawa z dnia 28 listopada 2014 r. Prawo o aktach stanu cywilnego tekst jednolity Dz. U. z 2016 r. poz. 2064 z późn. zm.

Ustawa z dnia 6 czerwca 1997 r. Kodeks karny tekst jedn. Dz. U. z 2017 r. poz. 2204 z późn. zm.

Written Comments by the Helsinki Foundation for Human Rights z dnia 25 lutego 2014 r. dost. tutaj: http://www.hfhrpol.waw.pl/precedens/images/Orlandi_amicus_ETPC.pdf [dostęp z dnia 21 maja 2018 r.].

Wyrok Europejskiego Trybunału Praw Człowieka z dnia 14 grudnia 2017 r. w sprawie Orlandi i Inni p. Włochom, skarga nr 26431/12

Wyrok Europejskiego Trybunału Praw Człowieka z dnia 21 października 2015 r. w sprawie Oliari i Inni p. Włochom skargi nr 18766/11 i 36030/11

Wyrok Europejskiego Trybunału Praw Człowieka z dnia 24 czerwca 2010 r. w sprawie Schalk i Kopff p. Austrii, skarga nr 30141/04

Wyrok Naczelnego Sądu Administracyjnego z dnia 17 grudnia 2014 r., sygn. akt II OSK 1298/13

Wyrok Naczelnego Sądu Administracyjnego z dnia 28 lutego 2018 r., sygn. akt II OSK 1112/16.

Wyrok Wojewódzkiego Sądu Administracyjnego w Gdańsku z dnia 14 stycznia 2016 r. sygn. akt III SA/Gd 835/15 
Wyrok Wojewódzkiego Sądu Administracyjnego w Gliwicach z dnia 6 kwietnia 2016 r., sygn. akt. II SA/G1 1157/15

Zob. M. A. Nowicki, Omówienie orzeczenia Orlandi i Inni p. Włochom, dost. tutaj: https://www.hfhr. pl/wp-content/uploads/2018/01/Omowienie_orzeczenia_Orlandi_i_inni_przeciwko_Wlochom-1. pdf [dostęp z dnia 21 maja 2018 r.].

\section{SUMMARY}

According to the Polish regulations, a person, who entered into marriage abroad, may request that to be transcribed - i.e. revealed in the Polish civil status records. Nevertheless, such transcription may not be demanded by all those, who entered into marriage abroad, even if all of the foreign legal requirements of marriage were granted.

Among others, it is impossible to transcribe to the Polish civil status records a gay marriage, concluded abroad. In the following article, the author will attempt to answer, whether current Polish legal regulations, according to which a marriage successfully concluded abroad, does not enjoy any legal recognition, and by extension - protection, complies with the minimal standards of human right protection, as envisaged by the European Convention on Human Rights and jurisprudence of European Court of Human Rights in Strasburg.

Keywords: Administrative law, transcription, civil status record, ECtHR, ECHR, Orlandi, Oliari, Schalk I Kopff, jurisprudence, LGBT; 